Goldschmidt 2021 Abstract

https://doi.org/10.7185/gold2021.7299

\section{Mafic dykes in the Northern and South-Eastern Siberian Craton with age of ca 1.4 Ga: remnants of Large Igneous Province and possible marker for Nuna break up?}

\author{
SERGEY MALYSHEV ${ }^{1}$, ALEXEI IVANOV ${ }^{2}$, VALERY \\ SAVATENKOV $^{3}$, OLGA LEBEDEVA ${ }^{4}$, VADIM \\ KAMENETSKY ${ }^{5}$, MAYA KAMENETSKY ${ }^{5}$, ALEKSANDER \\ M. PASENKO ${ }^{6}$ AND DARIA SITKINA $^{7}$ \\ ${ }^{1}$ Saint Petersburg University \\ ${ }^{2}$ Institute of the Earth's Crust SB RAS \\ ${ }^{3}$ Institute of Precambrian Geology and Geochronology RAS \\ ${ }^{4}$ A.P. Karpinsky Russian Geological Research Institute \\ ${ }^{5}$ University of Tasmania \\ ${ }^{6}$ Schmidt Institute of Physics of the Earth RAS \\ ${ }^{7}$ Institute of Precambrian Geology and Geochronology \\ Presenting Author: s.malyshev@spbu.ru
}

Mesoproterozoic on the Siberia craton is characterized as quiescence of the magmatic events. New finding of rare mafic dykes with $\mathrm{U}-\mathrm{Pb}$ ages at about $1.4 \mathrm{Ga}$ suggests the wide distribution of remnants of mafic intrusives in the region associated with the intracratonic crustal extension. We report geochemical and $\mathrm{Sr}-\mathrm{Nd}-\mathrm{Pb}$ isotope data on ca $1.4 \mathrm{Ga}$ dykes to show that they resemble a flood basalt association with an island arc-like continental basalts.

Two studied dykes are from Udzha uplift (northern part of Siberian Craton) and Sette-Dabar ridge (south-eastern part of Siberian Craton). Both dykes were dated with employing U-Pb on apatite and obtained ages are $1386 \pm 30 \mathrm{Ma}$ [1] and $1419 \pm 32$ $\mathrm{Ma}(\mathrm{MSWD}=0.3$ ), correspondingly. Trace element patterns show ocean island basalts or island arc-like profiles for Udzha dyke and a clear island arc-like profile for Sette-Daban low-Ti dolerite dyke. Isotope characteristics in both cases suggest a significant contribution of ancient recycled crust (subducted oceanic crust or delaminated low continental crust).

Similar ages (ca $1.4 \mathrm{Ga}$ ) were reported for numerous mafic dyke swarms from North American craton, Greenland, and Baltica [2 and references therein], which were assembled within the core on the Nuna supercontinent [3]. According to our study and taking into consideration data from intrusions of adjacent cratons in the Early Mesoprotherosoic mafic dykes show trace element variations similar to Phanerozoic large igneous provinces (LIP). The magmatic activity in Siberia Craton at the ca $1.4 \mathrm{Ga}$ could be linked with the reassembly continental blocks from Nuna to Rodinia supercontinents during Mezoprotherozoic.

The study is supported by Russian Scientific Foundation (grant No 19-77-10048).

[1] Malyshev, S. V. et al. Geodynamic Significance of the Mesoproterozoic Magmatism of the Udzha Paleo-Rift (Northern Siberian Craton) Based on U-Pb Geochronology and Paleomagnetic Data. Minerals 8, 555 (2018).

[2] Ernst, R. E. et al. Long-lived connection between southern Siberia and northern Laurentia in the Proterozoic. Nature
Geoscince 9, 464-469 (2016).

[3] Evans, D. A. D. \& Mitchell, R. N. Assembly and breakup of the core of Paleoproterozoic - Mesoproterozoic supercontinent Nuna. Geology 39, 443-446 (2011). 